conclusion, Mr. Lennox Boyd said that, in 1957, 1,689 officers were selected for appointment to the administrative or professional branches compared with 1,467 in 1956, and of these, 284, mostly on contract, were to Nigeria. Mr. Lennox-Boyd and other speakers paid warm tribute to the work, the loyalty, the efficiency, the integrity and the quality of the Overseas Service. In replying to the debate, he added that, although there was a substantial gap between demand and supply, we were recruiting at four times the pre-war rate over the whole field. At the end of 1957 there were 130 vacancies in administration and 1,384 in all branches, compared with 170 and 1,456, respectively, in 1956, and the proportion of vacancies to the total number of overseas officers in the service was now about 7 per cent. In Ghans, about 400 officers, or 50 per cent of those entitled to compensation, had retired since July 1955. Mr. Lennox-Boyd defended the Government's policy in regard to compensation as holding a reasonable balance between justice to those officers who wished to retire and the duty to try to induce them to stay. He explained that the recruitment and employment of experts under the technical co-operation scheme were covered by administrative action and it was not intended to change this procedure. Foreign Office appointments to South East Asia Treaty Organization posts were normally filled by secondment, but if a person from the Oversens Civil Service were recruited the provisions of the Bill could be applied if necessary.

\title{
MANAGEMENT TRAINING
}

$\mathrm{I}^{\mathrm{N}}$ the fourth Graham Clark Lecture to the Institution of Civil Engineers on December 17, on "The Engineer and Management", Sir Ewart Smith said that while science and its practical applications through engineering and chemical technology had shown that we were potentially able to meet any standard of national welfare mankind could desire, subject to some limit to world population with regard to natural resources, the rate of advance in science and technology was not being matched by progress in our ability to control and manage. Sir Ewart suggested that this might be due to our neglect in human affairs and organization of the guiding principles of simplicity, symmetry (or balance) and continuity. More research, better analysis and far better teaching in management subjects were needed, and it did not seem to be appreciated that the very growth of complexity and specialization increased the need to train with great care those who will have the responsibility of training the specialists.

Discussing selection and training for management, Sir Ewart emphasized the importance of regular, multiple and independent assessments of ability to men and management alike. Far too much weight was often placed on written examinations during the period of formal training, and in industry there was usually little systematic study of people to assess their potential and the best lines for their development. A main responsibility of the highest management should be to pick its own potential successors and to train them with the utmost care, from the early years of service, and Sir Ewart welcomed recent discussion on the general content of educetional courses ; it should be a question of how science and the humanities could be reunited in everyone who claimed to be reasonably educated, and he thought that the main change had to take place in the schools rather than in the universities. It was a mistake to think that three years was still an adequate period for a full university course in scientific and technological subjects, and Britain was almost unique among the great nations in its failure to make the changes in this respect which modern conditions demended. More time should be spent in teaching people how to use knowledge, and where they could find it in codified form when they required it in their working life. Good education, moreover, depended primarily on good teachers and relatively little on buildings and equipment. Emphasizing the importance of the engineer in management, Sir Ewart suggested that the main reason for our failure to utilize their services here has been the present acute shortage of technologists, which tends to confine them to specialist work. There was no reason to suppose that the incidence of natural ability, initiative and enthusiasm had diminished, but for Britain to attain her full economic strength the engineer must play a full part in leadership and in developing the most effective forms of organization and methods of management for a changing world.

\section{THE LINNAEUS TRADITION AND OUR TIME}

$I^{\mathrm{N}}$ his presidential address to the Swedish Academy on December 20, Mr. Dag Hammarskjöld took as his subject "The Linnaeus Tradition and our Time". He considered Linnaeus's contribution towards the development of velues which it is the task of the Academy to safeguard. Freshness and precision, enthusiasm without lyricism, an instinctive eye for meaning and causality raised the great travel accounts and his other Swedish writings far above the criticism he himself foresaw, and enriched his country's litersture by values as essential to our emotions as the Nature they mirror. Nevertheless, his style would scarcely have found its freshness had he not been guided by his sense for the striking and for the unexpected associations of humour. Linnaeus's Swedish works are perhaps read to an increasing extent even outside the circle of experts.

The relationship of a nation-and a generationto older literature tells something about the continuity of spiritual life. Outside the limits of belles lettres, the works of Linneseus occupy a place of their own in Sweden, whereas other books which have much to offer are neglected. 